Leaving out of account frictional generation of heat (in other words, the effect which varies as the square of the current), let $\sigma d \theta$ be the heat generated in unit time by unit current in a uniform copper bar, in passing from a section where the temperature is $\theta+d \theta$ to one where it is $\theta$ (see Thomson's "Papers," vol. i. p. 246). Let $x$ be distance along the bar in the direction of the current, and $c$ the thermal capacity of unit length of the bar. The heat generated in a short length $\delta x$ is $-\sigma \frac{d \theta}{d x} \delta x$, and the consequent rise of temperature in this portion is $-\frac{\sigma}{c} \frac{d \theta}{d x}$. This is in unit time. Hence, putting $t$ for time, and $z^{\prime}$ for $\frac{\sigma}{c}$, we have-

$$
\frac{d \theta}{d \ell}=-v \frac{d \theta}{d x}
$$

If the limits of temperature are not very far apart, it is known that $\sigma$ and $c$ are sensibly independent of $\theta$; hence $v$ may be treated as a constant. The integral of the above equation is then-

$$
\theta=F(x-v t),
$$

where $F$ is a functional symbol such that $\theta=F(x)$ expresses the original distribution of temperature. The interpretation is that the original "temperature curve" travels forward with velocity $v$ without flattening or any other change of form.

Belfast, May I4

J. D. Everett

\section{Scientific Nomenclature}

Some time ago Mr. "John O'Toole," in the columns of NATURE, waged war against that hideous monstrosity Potential Energy, and he very aptly summarised his case against this term by saying that it involves, by the very signification of words, "a double remotion from actuality."

A few months ago it occurred to me that to express what is intended by the potential energy of any system the term Static Energy is not only logically unobjectionable but specially fit for the purpose. Thus, if a string or a membrane is stretched, a wire bent and twisted, or, generally, a body strained in any manner, the work which it can do against resistance in returning from its state of strain to its unstrained condition is the Static Energy of the system in the strained condition. The work which a moving system can do in virtue solely of its motion is, of course, its Kinetic Energy.

Thus we have simply Static Energy and Kinetic Energy, and these terms have the further advantage of harmonising with the ordinary subdivisions of dynamics.

I may add that the term Static Energy has received the approval of all the mathematical physicists to whom I have submitted it.

R.I.E. College, Cooper's Hill, May I9 EORGE M. MiNCHIN

\section{Pendulum Oscillation}

THE oscillations of a long pendulum are observed to describe an ellipse the axis of which tends to set itself at right-angles to the plane in which the pendulum was started. An explanation of the above phenomenon would much oblige. M. H. MAW

Walk House, Barrow-on-Humber, Hull, May 18

\section{What is Histioderma?}

Histioderma hibernica was described by Dr. Kinahan in 1858 as an annelid, and most writers who have since mentioned it have also regarded it as such. Dr. Haughton notices and figures it in his "Manual of Geology," Sir R. I. Murchison places it amongst annelids in his "Siluria," as also Dr. Bigsby in hi "Thesaurus Siluricus." Writing from memory only, I think a description and figure will be found in W. H. Baily's useful compendium of Palæozoic British fossils, published a few years ago. The fossil is mentioned with more or less detail by numerous writers on Cambrian strata.

The above references will perhaps answer the letter signed "S.," but there still remains the question, What is Histioderma? It is apparently a fossil impression in the rocks of Bray Head, Wicklow, Ireland. Only one species and only one locality is, I believe, known. It seems to me very doubtful what kind of animal made the impression-whether an annelid, or otherwise. I am inclined to doubt if the rocks are Lower Cambrian, as geologists generally suppose, because the evidence seems to indicate that the Bray Head rocks had become hardened and raised into land before the oldest Lower Cambrians of Wales and England were deposited. I would therefore pass on the question and ask, What is Histioderma?

4, Cowper Road, Acton, London, W.

A. RAMSAy

IN answer to the above question in your issue of May 20 (p. 53), I refer your correspondent to the Proceedings of the Geological Society of Dublin, where he will find (Natural History Reviez, vol, v., Proceedings of Society, p. I50) the original description of Histioderma by Prof. Kinahan. According to its author, Histioderma is the tube of a cephalo-branchiate annelid.

Leipzig, May 23

J. VICTOR CARUS

\section{Black Skin}

IN a letter lately received from Mr. Flinders Petrie, who is now in Egypt, are some remarks on "Black Skin," which I think very interesting, and perhaps the readers of NATURE may think them so too, so I send the paragraph to you.
Belvedere, Kent, May 24
F. C. J. Spurrell.

"In considering the use of a naturally or artificially black skin, we should not look so much to the requirements of the surface, which is constructed to bear variations, and has the means of cooling and maintaining a proper temperature within itself, but rather we should consider the far more delicate tissues beneath. We all know how translucent flesh is to strong light, and it can hardly be doubted that the rays of a tropical sun would light up a white man's inside considerably; whereas black skin would stop out the solar energy of light, heat, and chemical rays effectually. Skin heat is of no importance, as perspiration can always keep that down. May not the oiling of the skin in hot countries be partly to make it reflective, so that it should absorb less heat? And may not the regard white races have for clothing be partly for the purpose of keeping the insides of their bodies sufficiently in the dark?"

\section{Male Animals and their Progeny}

CAN any of your correspondents inform me whether any of the male wild animals in foreign countries show any love for, or recognition of, their progeny? In this country amongst the domestic animals it does not seem to exist, save in the case of the gander, who carefully guards the goose while sitting, and attends to the goslings when hatched; but the cock pays no attention to the hen while sitting nor when with chickens, nor does the dog, the bull, the horse, nor the boar evince any sign of parental feeling under circumstances favourable to its development.

One peculiarity of geese is, I think, worthy of notice, for it is not possessed by ducks or fowls, who also live in flocks. If when goslings are hatched, they are permitted to run with a goose in company with the other geese of the flock, all chances of any eggs being laid by the other geese who have no goslings are over.

P.

\section{Birds and Mirrors}

For six days I have been for two or three hours in the club reading-room, where t'ere is a large mirror. During all this time a cock and hen sparrow have been flirting with and bowing to their images in the glass with evident pleasurerushing along the mantel-shelf, flying to the top of the frame, or resting for a time, always apparently happy in contemplation, never showing disappointment. F. C. CoNSTABLE

Sind Club, Karáchi, May 2

\section{SURGEON-MAFOR T. R. LEWIS}

$\mathrm{D}^{\mathrm{R}}$ R. TIMOTHY LEWIS, Surgeon-Major Army Medical Staff and Assistant Professor of Pathology in the Netley Army Medical College, whose death, which took place on May 7, we announced last week, was a native of South Wales, and received his medical education at University College, London, and graduated as M.B. at Burlington Gardens. He was selected about twenty 
years ago, together with Dr. Cunningham, to proceed to India in order to undertake, under the auspices of the Indian Government, a prolonged study of the causation of cholera, especially in regard to its reputed relation to parasitic organisms. At that time little was known or thought about Bacteria, and the public mind had been aroused by Hallier's (now long-exploded) theory of a ricefungus as the cause of cholera, just as more recently it has responded to Dr. Koch's invitation to believe in the comma-bacillus. Dr. Lewis and his companion were authorised to visit Prof. Hallier at Jena and Prof. de Bary (in those days not attached to French Strasburg !) for the purpose of acquainting themselves with methods of mycetological research before proceeding to India. A few weeks was all the time allowed them for this visit, and consequently they took little to India excepting their own conscientious habits of work and that modicum of knowledge of microscopic technique which was considered sufficient for the highest medical qualification in England in those days. Nevertheless these observers made most valuable and minute researches on the microscopic organisms present in the dejecta of cholera-patients, which were published by the Government of India. Dr. Lewis extended his researches into the general question of the presence of microscopic organisms in the blood and tissues of man in health and disease, and was led to some very interesting discoveries. His results were published from time to time by the Government of India, and were re-published as they appeared in the Quarterly Fournal of Microscopical Science.

Dr. Lewis's work was always remarkable for the extreme care with which positive results were asserted, and for the fairness with which the researches of predecessors in the same field were considered and discussed. His most remarkable discovery was that of the little nematoid worm occurring in the blood of persons suffering from a form of chyluria and elephantiasis, to which he gave the name Filaria sanguinis hominis. This discovery was published in 1872 . Some years later Dr. Bancroft discovered in Australia the adult worm from which the brood of minute blood-parasites is derived, and, still later, an unsuccessful attempt has been made by Dr. Patrick Manson to show that the young pass an intermediate stage of existence in the alimentary canal of gnats, which suck them in together with the blood of worm-infested persons.

It is no small thing in these latter days to discover a new human parasitic worm of great pathological significance, and it was in recognition of this discovery, as well as in view of his important contribution to the discussion of "the cholera-bacillus theory," that the Council of the Royal Society in last April selected Dr. Timothy Lewis as one of the fifteen candidates to be submitted to the Society for election in next June.

In regard to the question of the relation of Bacteria to cholera and similar diseases, Dr. Lewis had a vast store of both published and unpublished observation. With characteristic caution and modesty, he had refrained from dogmatising on the subject. Working for twelve years in Calcutta, with daily access to cholera patients, he was thoroughly familiar with the several different forms of Bacteria which are to be found in the alimentary tract and in the dejecta of choleraics. Unlike some of his recent successors in this line of research, Dr. Lewis was also familiar with the different forms of Bacteria which occur in the healthy human mouth and intestines, and in potable waters. He was therefore able to demonstrate. immediately on the publication of Koch's figures of the so-called "comma-bacillus" that this form (asserted by Koch to be peculiar to cholera evacuations) was nothing more nor less than a Spirillum broken by manipulation, and commonly to be found in the mouth of healthy persons. The importance of this contribution to the controversy excited by Dr. Koch's statements cannot be too highly estimated. Its accuracy was uni- versally recognised at once, and has never been called in question. Dr. Klein has since come to the conclusion that not only are organisms of the exact form of Koch's cholera-comma abundant in the healthy saliva, as shown by Lewis, but that some of these forms have precisely the same physiological conditions of growth, and precisely the same action upon gelatine as Koch considered to be characteristic of those obtained from cholera evacuations.

At the time of his death Dr. Lewis was carrying on in his laboratory at Netley an extensive series of culture and inoculation experiments, chiefly upon the Bacteria which occur in the alimentary canal of man.

Those who enjoyed his personal friendship valued Dr. Lewis for his warm-heartedness no less than for the rare combination of enthusiasm with caution in his work which gives his published results a very special value. It is perhaps some satisfaction to his friends to know that he had heard of the recognition of his merits by the Royal Society Council before the commencement of the attack of inflammation of the lungs which so rapidly ran to a fatal termination.

E, R. L.

\section{A SKETCH OF THE FLORA OF SOUTH AFRICA}

UNDER this title we would draw the attention of botanists to a very able essay on the botanical regions of South Africa, contributed to the "Official Hand-Book of the Cape of Good Hope" for 1886, by Harry Bolus, F.L.S., an accomplished botanist, who has devoted many years to the investigation of South African plants.

That extra-tropical South Africa is one of the most varied botanical regions on the globe is a fact familiar to both botanists and gardeners, from the days of Linnæus,who epitomised its richness in the expression, "Ex Africâ semper aliquid novi,"-and of the earliest cultivators of greenhouse plants, who were indebted to the Cape of Good Hope, far more than to any other regions of the globe, for what were, and till Japan and Australia eclipsed it, the prime favourites of the conservatory. There are those still alive who can remember the time when planthouses were ornamented with little else than Cape Heaths, Pelargoniums (miscalled Geraniums), Polygalas, Proteas, Oxalis', Mesembryanthemums, Everlastings, Stapelias, Irideæ, and Cape bulbs innumerable, and when the illustrated horticultural serials of the day were either devoted to these, or contained figures of more of the plants of this than of any one other country: It is true that the cultivation or all but a very few of the heaths and geraniums has been abandoned for things of not greater beauty, and of far less interest, but this is due, not to want of appreciation, but in the case of some to their not being amenable to the treatment of the "soft-wooded" plants now in vogue, and of others to the fact that their flowering period - of the bulbs especially-is a very brief one, and that the flowers soon fade when cut.

To return to the little essay before us: the attempt to define the South African regions of vegetation is not a new one; it had been essayed by Meyer and Drège, Zeyher, Griesebach, and others, but not successfully; and the author of the sketch under consideration is the first who has succeeded in presenting satisfactorily the salient botanical characters of that flora, as affected by, or in correspondence with, geographical and other physical conditions; whilst he alone has given such vivid pictures of the vegetation of the different botanical regions he has defined, that any one with even an elementary knowledge of South African plants can fancy himself travelling over the ground.

The two dominant features of the South African flora are, the number of orders, genera, and species that it contains, and the limitation of great groups of these 